\title{
DETERMINATION OF ENVIRONMENTAL PERCEPTIONS AND AWARENESS TOWARDS REDUCING CARBON FOOTPRINT
}

\author{
AKTEN, M. ${ }^{1^{*}}-$ AKYOL, A. $^{2}$ \\ ${ }^{I}$ Department of Landscape Architecture, Architecture Faculty, Suleyman Demirel University \\ 32260 Isparta, Turkey \\ ${ }^{2}$ Department of Forest Engineering, Faculty of Forestry, Isparta University of Applied Sciences \\ 32260 Isparta, Turkey \\ *Corresponding author \\ e-mail:muratakten@sdu.edu.tr \\ (Received $13^{\text {th }}$ Jun 2018; accepted $31^{\text {st }}$ Jul 2018)
}

\begin{abstract}
In today's world where humans have exceeded limits of the planet, natural resources are becoming increasingly important. Together with the concept of sustainable living, making the agenda to conduct ecological measurements in the early 1990s, the concept of ecological footprint offers great contributions to creating ecological risk profiles. Today, it can be seen that many countries' Ecological Footprint exceeds their biocapacity. One of the most important components of the concept, carbon footprint is strongly associated with society's consumption forms, perceptions and attitudes. In this study carried out in Izmir province, in Turkey, trends and perceptions towards reducing ecological footprints left by society were analysed within the scope of ecosystem services using survey method. As a result of the study, it has been observed that ecological deficit emerging as a result of humans' perspectives on the natural environment and their consumption habits is increasing with each passing day.
\end{abstract}

Keywords: natural resources, ecosystem services, ecological footprints, society trends, sustainability

\section{Introduction}

Environmental and social effects caused by modern societies measuring prosperity level with consumption are one of the most important current problems of humanity. In terms of seriousness of its magnitude, a need has emerged to develop new policies at global level. Within the framework of sustainable growth and due to economic and environmental problems including recent economic crisis, climate change etc., and new concepts have emerged such as environmental sustainability, green economy, green growth, low-carbon economy, sustainable production and consumption (Öztürk, 2012; Velioğlu and Aydın, 2017). In terms of Resource Efficiency Policies, it is necessary to keep damages given to natural life at minimum, ensure economic growth in a way to sustain world resources, thus, there is a need to determine level of efficient consumption of resources in terms of exhaustible resources (Reyhan, 2014).

Within the scope of United Nations Development Programme (UNDP) and United Nations Environment Programme (UNEP), an organization was established in which economic development and environment were discussed as two inseparable aspects together with "Climate Partnership" and "Poverty and Environment Fund" initiatives launched in Nairobi-Kenya as of February 2007. While Poverty and Environment Fund aims at improving environmental management and increasing environmental investments, Climate Partnership Initiative emphasizes capacity increase in terms of technology transfer and more in developing countries' fight against climate change. Thus, boundaries of ecology which was initially considered only as a natural sciences discipline rapidly 
expand towards both economic and social fields, it is becoming increasingly possible for economy and ecology to meet on a common ground with social content.

Exceeding biophysical boundaries leads to damaging of systems that form basis of natural balance and economy. This situation, however, makes it more difficult to reach a certain quality of life in the future and maintain such a life. However, complex structure of natural systems makes it difficult to identify at which point lifestyle associated with consumption level strays from sustainability. Ecological Footprint is an indicator that measures ecological footprint in certain categories within the framework of narrow definition of natural services benefited from. Developed by Mathis Wackernagel and William Rees in early 1990s, this concept is defined in the form of production of natural resources containing agriculture, livestock, fishery and forest products and $\mathrm{CO}_{2}$ emission, and in the form of biological productive field required to meet these demands (Ewing et al., 2010). Calculation of ecological footprint is extremely important in terms of seeing how much humans behave over the biocapacity while meeting their needs and in terms of determining how much humans use their natural resources by comparing countries' ecological footprints with biocapacity (Coşkun, 2013).

Ecological Footprint of Turkey in 2007 was 2.7 global hectare (gha), and this rate is equal to world average, and lower than the average of Mediterranean countries. Ecological Footprint of consumption in Turkey is $50 \%$ over global biocapacity per capita. This case is the sign of a non-sustainable lifestyle in Turkey as in the rest of the world. Since national biocapacity of 1.3 gha per capita is below world average ( 1.8 gha/person) in Turkey, its national ecological debt is much higher than its global deficit. This deficit called as "ecological limit excess" results in supplying biocapacity need partially from abroad.

Countries that calculate ecological footprint and analyse its outcomes will be able to determine ways to eliminate risks associated with ecological deficit. For our country and more importantly for the future of our world, we need to reduce our ecological footprint. Beyond our individual responsibilities with a view to reduce ecological footprint and promote more sustainable lifestyles, there are also some other designs that we should adopt globally (Keleş, 2007). One of the most important components of ecological footprint concept is carbon footprint. Carbon footprint is strongly associated with society's consumption forms (Ebad1, et al., 2016), perceptions and attitudes.

The aim of this study is to examine ecological footprint data of Turkey within the scope of ecosystem services, and to find out society's economic and social attitude on the subject. To do this, participants' carbon footprints were calculated based on their consumption data. Thus, it is considered that this study will contribute to definition of development goals that also consider environmental sustainability by means of preparing ecological footprint statement, and will contribute to determination of individual and social responsibilities to reduce adverse ecological affects emerging depending on the use of natural resources. In this sense, children and the young who will be individuals of the future and who should receive environmental education at an early age will see the concept of ecological footprint and limits of our consumerism as a society (Öztürk, 2010).

\section{Theoretical foundations}

\section{Ecosystem services}

Scientific history of the concept of ecosystem services dated back to the 1970s, use of this concept in the literature gained speed in the 1990s (De Groot et al., 2010). The 
concept of "Ecosystem Services" was defined firstly by Daily (1997) as "ecosystems required for maintaining human life, and situations and processes carried out by species". Costanza et al. (1997) describe ecosystem services as benefit from ecological functions; De Groot et al. (2002) describe them as benefits from both processes and functions; Boyd and Banzhaf (2007) describe them as only directly benefited products (Çoban and Yücel, 2018).

This concept has become more widespread with the United Nations Millennium Ecosystem Assessment (MEA) report published in 2015. In this report, while ecosystem services were described as natural capital, it was emphasized that natural capital's capacity of supporting future generations with human activities decreased. The second major international study following the MEA report is the research titled "The Economics of Ecosystem and Biodiversity (TEEB)" which emerged with the initiative of UN Environment Program. One of the most important objectives of TEEB report in which biodiversity, economics and interdisciplinary work was "to emphasize increasing costs of biodiversity loss together with degradation in ecosystem" (Demiroğlu and Karadağ, 2015). The concept of ecosystem services was discussed, interpreted and defined in different ways by associating more with ecosystem process and biodiversity subjects. Basically, ecosystem services are also defined as "situations, processes, functions, benefits and all products provided by ecosystems to maintain human life and ensure welfare among humans" (Albayrak, 2012).

Ecosystem services, in addition to the manufacture of products, also includes many life support functions such as regulation of climate, maintaining soil and flood control, clean-up, recycling and renovation of natural resources. In MEA report, ecosystem services were discussed by welding classifying them in 4 major ecological function groups including resource providing services, regulating services, cultural services and supporting services, and under 30 categories. In the TEEB report, ecosystem services were discussed by classifying in 4 major ecological function groups including resource providing services, regulatory services, culture and comfort services and habitat services, and under 22 categories (Table 1).

Today, the subject of ecosystem services is addressed as an important issue by government agencies, academicians, non-governmental organizations and the private sector. For example, one of the most important international conventions in which Turkey is also a party, United Nations Biodiversity Convention defines actions towards the protection of ecosystems and services they provide within the scope of Aichi Biodiversity Objectives.

The importance of ecosystem services is accepted not only with regard to processes of biodiversity but also in the field of sustainable development. In "Sustainable Development Summit" held in 2015, 17 Sustainable Development Objectives were determined by United Nations member countries to end poverty, to eliminate inequality and injustice and to fight against climate change until 2030. In this respect, protection, restoration and maintenance of ecosystems and their services were defined under various objectives. Addressing ecosystem services in such distinct conventions and legal processes is an indication of further increase in importance of this issue at global scale (URL-1, 2018).

However, social and economic development of community and thus providing a quality life have brought along many problems. Today, more than $50 \%$ of the world's population live in cities, and it is estimated that this figure will reach $70 \%$ in the year 2050 (Anna et al., 2016). Since urbanization changes forms of personal land use, 
transportation, industrial and agricultural production, consumption and social activities, it adversely affects natural resources. Scattered development of modern cities and expansion to large areas have adversely affected natural habitats. For example, Thailand has lost $96 \%$ of its wetlands, Australia has lost $95 \%$ of its wetlands, and USA has lost $53 \%$ of its wetlands (Çoban and Yücel, 2018). This situation has resulted in increasing importance of natural resources and growth of human-induced ecological footprints threating natural resources. In this context, the concept of Ecological Footprint has become one of most popular and widespread indicators for sustainability assessment and resource management.

Table 1. Classification of ecosystem services: MEA (2015) and TEEB (2015) classifications

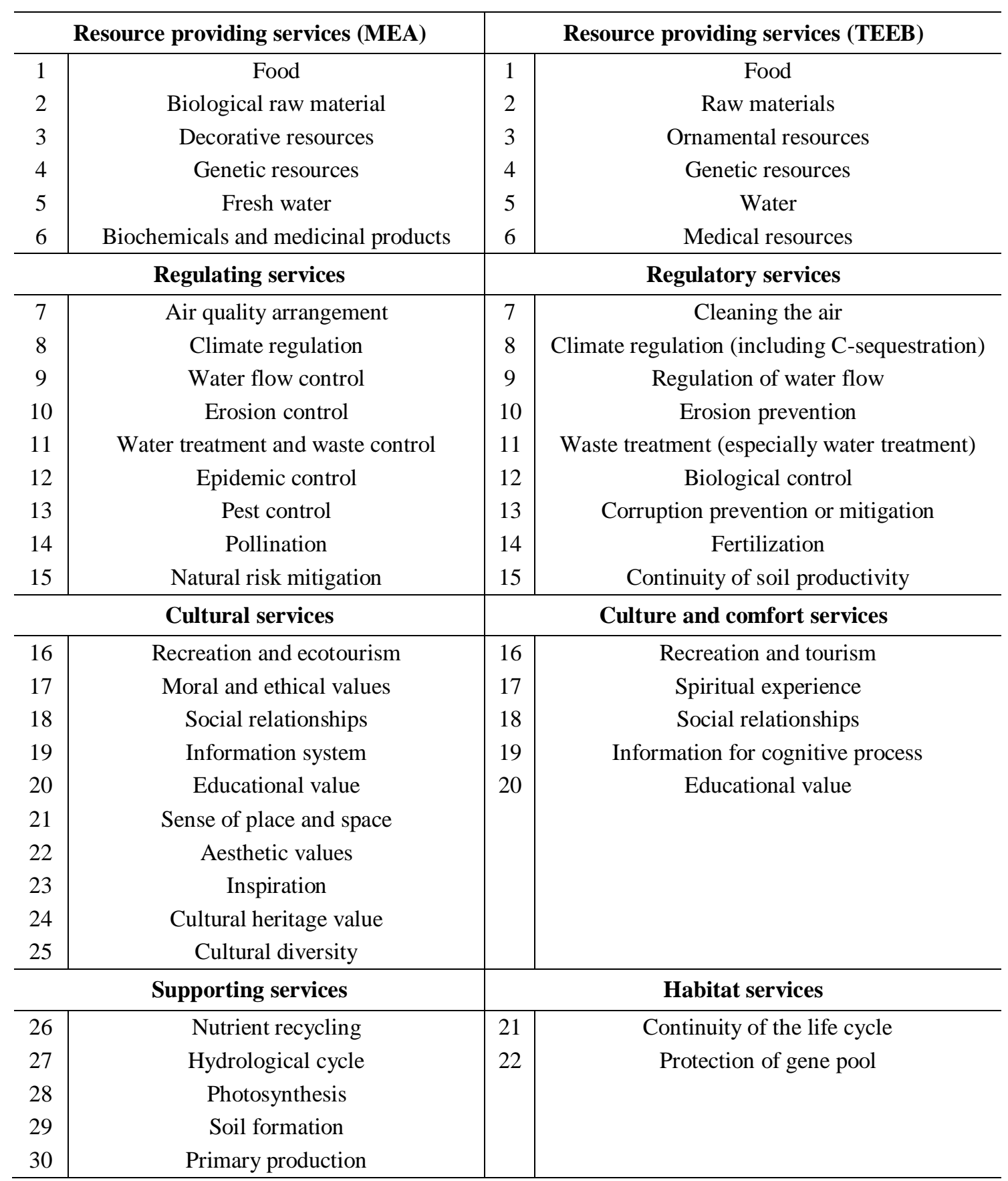


Concept of ecological footprint was firstly developed by Mathis Wackernagel and William E. Rees in early 1990s and used to conduct ecological measurements. This criterion denominates biologically productive soil and water field in global hectares that are required for production of resources consumed and disposal of waste created in the meantime by means of existing technology and resource management (Wackernagel and Rees, 1996; Tosunoğlu, 2014). Biocapacity, on the other hand, is indicator of production capacity of renewable natural resources in a geographical region. In other words, ecological footprint refers to used resource, and biocapacity refers to available resources. Identification of global hectare is used for measurements. A global hectare represents the production capacity of 1-hectare field over world's average efficiency. Thus, total amount of resources obtained from different types of field within a certain period of time and demand for these resources are degraded to a common unit and expressed in numeric values (WWF, 2012). This allows consistent measurement of global ecological footprint and biocapacity and comparison with each other (Wilson and Anielski, 2005; Wackernagel et al., 2014).

Ecological footprint is an important criterion that reveals how much land and water are needed to reproduction of natural resources consumed and recovery of wastes emerging in the meantime. This, in a way, describes the load that mandatory consumption of natural resources by humans to survive in this world establishes over sustainability of ecosystem (Keleş, 2007). As a part of nature, humans meet their biological and cultural needs from nature. Everyone has a powerful effect on the world. As a result of production and consumption, the sum of these effects creates ecological footprints. Many behaviors we do with habits brought along by our lifestyles actually result in growth of our carbon footprints (Kaypak, 2013). Ecological footprint, in general, is obtained by calculating components such as carbon footprint, cropland footprint, forest land footprint, grazing land footprint, built-up land footprint and fishing grounds footprint (WWF, 2012; Mancini et al., 2016).

\section{Ecological footprint components and status in the world and Turkey}

Natural balance of world's ecosystem is broken every day, and natural resources are insufficient to meet humans' needs. According to data from WWF (2012) Turkey's Ecological Footprint Report, Turkey's ecological footprint has tripled since 1961. In world ranking, Turkey is in the 63rd place among 154 countries (WWF, 2012). Analysing global ecological footprint and biocapacity rates per capita in Figure 1, it is remarkable that global ecological footprint started to exceed world's biocapacity in the 1970s and ecological deficit began to occur. Today, this deficit still continues to increase. Continuation of such increase in global footprint will bring along many problems.

In Figure 2, Turkey's ecological footprint and biocapacity rate are given. Analysing Figure 2, it can be seen that total ecological footprint in Turkey began to exceed national biocapacity for the first time in 1977, and this deficit continued increasing in following years. While Turkey's ecological footprint per capita was equal to global footprint average in 2005 with 2.7 gha, biocapacity per capita in the country was 1.3 gha. This situation shows that national level ecological debt among people living in Turkey is higher than world average. According to data from WWF (2012) Turkey's Ecological Footprint Report, percentage distributions of Turkey's global ecological footprint as per components are given in Table 2. Accordingly, carbon footprint created $55 \%$ of total footprint. Following the carbon footprint, cropland footprint is the second 
biggest component threating the global ecological system with a rate of $21 \%$. These are followed by forest land, grazing land, built-up land and fishing grounds footprints respectively. The fact that the carbon footprint ratio has such a large share requires focusing primarily on the carbon footprint. For example, the use of renewable resources instead of fossil resources will contribute significantly to reducing carbon footprint and thus reducing ecological footprint (Özsoy, 2015).

\section{World}

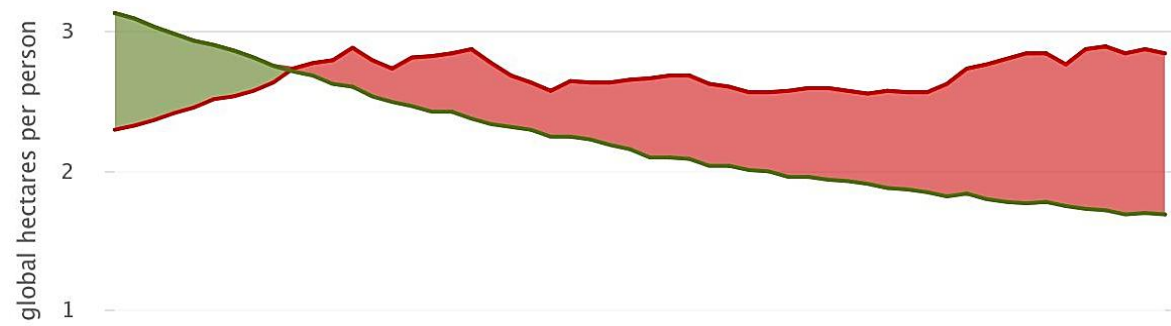

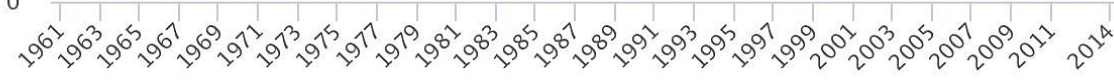

- Ecological Footprint - Biocapacity Ecological Deficit

Global Footprint Network, 2017 National Footprint Accounts

Figure 1. The world's ecological footprint and biocapacity status (URL-2, 2018)

\section{Turkey}

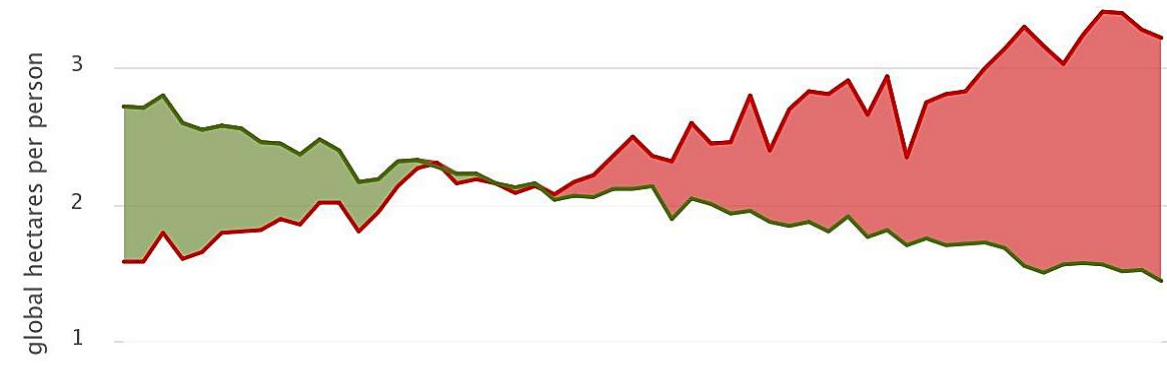

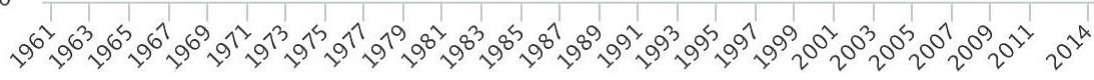

Ecological Footprint - Biocapacity Ecological Deficit
Ecological Reserve

Global Footprint Network, 2017 National Footprint Account

Figure 2. Turkey's ecological footprint and biocapacity status (URL-2, 2018) 
Table 2. Turkey's ecological footprint components (WWF, 2012)

\begin{tabular}{c|c}
\hline Ecological footprint components & Portion \\
\hline Carbon footprint & 0.55 \\
Cropland & 0.21 \\
Forest land & 0.10 \\
Grazing land & 0.08 \\
Built-up land & 0.03 \\
Fishing grounds & 0.03 \\
\hline Total & 1.00 \\
\hline
\end{tabular}

Seeing from which consumption category our personal footprint is originated is important in terms of understanding the relationship between our daily activities and usage of natural resources. Price of footprints is paid by the whole world in different forms. Humanity must find way to live in limits of capacity of natural resources as soon as possible and implement this way rapidly for a sustainable life, change their understanding of development and differ their consumption/management of natural resources. That is because there are no other planets to live. For this reason, it is necessary to maintain global biocapacity to ensure that current resources we use for meeting our needs will also be beneficial to future generations (Dinç, 2015). These socially, economically and ecologically left traces are not only personal but also social traces. To reach sustainability, both individualistic lifestyles should be analysed and resource productivity in social expenses should be questioned (Akman et al., 2000).

\section{Materials and methods}

Damages towards nature due to insensible usage of resources are increasing day by day, consequent adverse effects are felt more seriously especially in metropolises. In addition, consumptions among people living in metropolises and congruently their calculated global footprints tend to be higher. Therefore, the 3rd largest country of Turkey, İzmir, was selected in the study. İzmir province is located in the West of Turkey, in the coast of Aegean Sea. In İzmir, Mediterranean climate is dominant with hot and dry conditions in summer and warm and rainy condition in winter, annual precipitation is between $700-1200 \mathrm{~mm}$. In terms of flora, its flora is under the influence of Mediterranean climate, and all kinds of Mediterranean plants grow in the province. In terms of field distribution, forest fields take $41 \%$ share, agricultural lands take $28 \%$ share, grass-pasture lands take $4.5 \%$ share, and other type of lands take $26.5 \%$ share (URL-3, 2017).

Research data was collected with a survey study carried out with observation and interview operations. Survey study was carried out with survey forms created for this purpose in February-April 2017. In this sense, the path followed in the study was in the form of (1) collecting necessary files-documents required for the research by means of literature analysis, (2) survey-interview studies towards participants, and (3) statistical analysis and evaluation of obtained data. In survey forms, questions towards determining socio-demographic characteristics and multiple-choice questions towards 
participants' attitudes and perceptions were used. To determine participation in propositions, five-point Likert-type scale was used. In preparation of survey form, studies conducted by William (1992), Wackernagel and Rees (1996), Wilson and Anielski (2005), Keleş et al. (2008), Deniz and Ok (2016) Pamukoğlu et al. (2017) and Özmış and Tolunay (2017) were also used as reference. In accordance with objective of the study, questions prepared for calculating carbon footprint data among components of ecological footprint were based on questions used worldwide to calculate carbon footprint with a view to meet the standard and conduct comparisons. Carbon footprint was preferred in calculations since it is a component that can be increased or decreased depending on people's, thus society's, perception, attitudes and consumptions, and since it can be reduced with education, personal awareness and sense of responsibility. For this purpose, data was collected related to participants' food choices, organic food consumption amounts, dressing preferences, imported food and product consumption preferences, furniture and electronic appliances consumption preferences, recycling preferences, amusement activities, annual energy consumption amounts and annual travel conditions. $\mathrm{CO}_{2}$ emissions occurring as a result of these activities were calculated with "Carbon Footprint Calculator" (URL-4, 2017).

Survey was carried out with the participation of 221 people. Survey forms were analysed using SPSS 20.0. In analyses, primarily all questions and answers were digitized as per order statistics, and frequencies and percentages were utilized according to characteristics of question. Kolmogorov-Smirnov and Shapiro-Wilk-W tests were used to determine whether data was parametric or not, it was determined that, at $95 \%$ confidence level, data did not have normal distribution $(\mathrm{P}<0.05)$, in other words, not parametric (Mendes and Pala, 2003). Chi-square $(\chi 2)$ independence test was used to check whether there were relationships among some variables (Eymen, 2007; Kalayc1, 2010). As a result of reliability analysis conducted for expressions provided in five item Study five-point Likert-type, Cronbach's Alpha value was calculated as 0.702. Alpha is an important concept in assessment of surveys and measurement of internal consistency, it tests how much closer a group of items is associated as a group and how much reliability a study offers (Tavakol and Dennick, 2011).

\section{Results}

\section{Profile characteristics}

Within the scope of the research, participants were asked some socio-demographical questions on their age, gender, education, work/professional status and monthly income. Analysing Table 3, it can be seen that a total of 221 people has participated in the study, 127 of them are female $(57.5 \%)$, 94 of them are male $(42.5 \%)$. In the study, five different education groups were formed. Educational status is one of most important factors for affecting, changing and guiding studies for participants' perceptions and attitudes. Obtained data shows that rate of participants with university graduate and postgraduate education is high. The participants were categorized into seven different professional groups. Especially unemployed and housewives were defined as separate groups. That is because housewives' attitudes towards food shopping, dress shopping and energy consumption have a decisive role on the footprint left by household. The participants were categorized into five income groups based on income level. The minimum wage is approximately 2000 TRY in Turkey (CSGB, 2018). This situation shows that $53.4 \%$ of participants have an income at minimum wage level. 
Table 3. Profile characteristics of participants

\begin{tabular}{c|c|c|c}
\hline Characteristics & Group & n & \% \\
\hline \multirow{2}{*}{ Gender } & Female & 127 & 57.5 \\
& Male & 94 & 42.5 \\
\hline \multirow{3}{*}{ Age } & $18-30$ & 80 & 36.2 \\
& $31-40$ & 63 & 28.5 \\
& $41-50$ & 41 & 18.6 \\
& $51-60$ & 23 & 10.4 \\
& $60<$ & 14 & 6.3 \\
\hline \multirow{3}{*}{ Education } & Primary school graduate & 41 & 18.6 \\
& Secondary school graduate & 15 & 6.8 \\
& High school graduate & 61 & 27.6 \\
& University graduate & 88 & 39.8 \\
& Postgraduate & 16 & 7.2 \\
\hline \multirow{3}{*}{ Occupation } & Officer & 69 & 31.2 \\
& Self-employed & 40 & 18.1 \\
& Engineer & 38 & 17.2 \\
& Housewives & 21 & 9.5 \\
& Unemployed & 21 & 9.5 \\
& Retired & 19 & 8.6 \\
& Educator & 13 & 5.9 \\
\hline \multirow{3}{*}{ Income level (TRY) } & $0-1000$ & 43 & 19.5 \\
& $1001-2000$ & 58 & 26.2 \\
& $2001-3000$ & 14 & 6.3 \\
\hline & $3001-4000$ & $4000<$ &
\end{tabular}

\section{Participants' preferences related to reduction of carbon footprints}

Generally accepted questions were used in survey form with a view to calculate participants' carbon footprints, ensure consistency and make comparisons. Calculations were carried out with "Carbon Footprint Calculator" tool (URL-4, 2017). Analysing participants' answers given to these questions, participants' total carbon footprint, carbon footprint per participant and average carbon footprint amount per participant were calculated approximately. Besides, number of trees to be planted for reducing and compensating carbon footprint was determined approximately (Table 4).

Table 4. Information regarding participants' ecological footprints

\begin{tabular}{c|c|c|c|c}
\hline \multirow{2}{*}{$\begin{array}{c}\text { Number of } \\
\text { participants }\end{array}$} & \multirow{2}{*}{$\begin{array}{c}\text { Average } \mathbf{C O}_{2} \text { emission } \\
\text { (ton/person) }\end{array}$} & \multirow{2}{*}{$\begin{array}{c}\text { Total } \mathbf{C O}_{\mathbf{2}} \\
\text { emission (ton) }\end{array}$} & \multicolumn{2}{|c}{$\begin{array}{c}\text { Number of trees to be planted } \\
\text { for reduction }\end{array}$} \\
\cline { 4 - 5 } & & & Per person & Total \\
\hline 127 (Female) & 5.22 & 662.94 & 8 & 976 \\
94 (Male) & 8.62 & 810.28 & 12 & 1162 \\
\hline 221 & 6.67 & 1473.22 & 10 & 2210 \\
\hline
\end{tabular}


Analysing Table 4, while the amount of $\mathrm{CO}_{2}$ emissions per capita among women is 5.22 tons, the amount of $\mathrm{CO}_{2}$ emissions per capita among men is 8.62 tons. Assessing the situation in terms of total amount of $\mathrm{CO}_{2}$, women's total amount of $\mathrm{CO}_{2}$ emission was calculated as 662.94 tons approximately, and men's total amount of $\mathrm{CO}_{2}$ emissions was calculated as 810.28 tons approximately. As long as a tree lives, it converts approximately 0.73 tons of $\mathrm{CO}_{2}$ (URL-4, 2017). Accordingly, to compensate 810.28 tons of $\mathrm{CO}_{2}$ produced by male participants, approximately 12 trees per capita and a total of 1162 trees should be planted. To compensate 662.94 tons of $\mathrm{CO}_{2}$ produced by women, approximately 8 trees per capita and a total of 976 trees should be planted. Total amount of $\mathrm{CO}_{2}$ emission produced by 221 participants in the study is approximately 1473.22 tons. The amount of average $\mathrm{CO}_{2}$ emission per capita is 6.67 tons, number of trees to be planted per capita for compensation of 6.67 tons of $\mathrm{CO}_{2}$ produced is approximately 10 pieces. Number of trees to be planted for compensation of 1473.22 tons of $\mathrm{CO}_{2}$ produced is approximately 2210 pieces.

One of the most important services that forest ecosystems are received within the scope of ecosystem services is carbon storage and thus reduction of carbon footprint (Coşkun and Gençay, 2011). In this context, participants' opinions on whether they will provide financial support to afforestation studies for reducing their carbon footprints they have left are presented in Table 5. According to findings obtained, $71.5 \%$ of participants reported that they may support afforestation in different amounts, and $28.5 \%$ of them reported that they would not support such studies. Analysing Table 5, 54 of participants indicated that they would contribute an amount of TRY 10, 25 of them would contribute TRY 20, 21 of them would contribute TRY 30, 14 of them would contribute TRY 40, 8 of them would contribute TRY 50 and 36 of them would contribute TRY 100.

Table 5. Participants' amounts of contribution to afforestation works

\begin{tabular}{c|c|c|c|c|c|c|c|c}
\hline $\begin{array}{c}\text { Amount of support } \\
\text { (TRY) }\end{array}$ & $\mathbf{1 0}$ & $\mathbf{2 0}$ & $\mathbf{3 0}$ & $\mathbf{4 0}$ & $\mathbf{5 0}$ & $\mathbf{1 0 0}$ & $\begin{array}{c}\text { Not giving } \\
\text { support }\end{array}$ & Total \\
\hline $\begin{array}{c}\text { Participants } \\
\text { Percent (\%) }\end{array}$ & 54 & 25 & 21 & 14 & 8 & 36 & 63 & 221 \\
\hline $\begin{array}{c}\text { Total amount of } \\
\text { support (TRY) }\end{array}$ & 540 & 420 & 630 & 560 & 400 & 3600 & 0 & 6150 \\
\hline
\end{tabular}

With reference to these data, calculations towards afforestation works to be conducted for compensation of carbon footprint left by participants and relevant costs were made in accordance with the communique no. 298 issued in 2014 by General Directorate of Forestry (GDF) (OGM, 2014). Red pine species (Pinus brutia Ten.) was selected for calculations, since this species was suitable for ecological conditions of study area and it has been used in afforestation works by GDF. Accordingly, according to bill of costs for afforestation in 2016 issued by GDF, afforestation cost for 1 hectare of pine trees (Pinus brutia Ten.) is around TRY 12480 for İzmir province. Number of pine trees that should be included in 1 ha varies between 150-250 units depending on yield strength. Since number of trees to be planted for 1473.22 tons of $\mathrm{CO}_{2}$ produced by 221 participants is a total of 2210 and considering the fact that number of pine trees to be planted in a hectare is accepted as 200 pieces, there is a need for approximately $2210 / 200=11$ ha of afforestation. Since afforestation of 1 ha field is TRY 12248, there 
is a need for a total of $11^{*} 12480=$ TRY 137280 investment for 11 ha field. Participants indicated that they would contribute an amount of approximately TRY 6150. Deducting the obtained contribution amounts from the total amount of investment needed, an investment amount of 137280-6150 = TRY 131130 should be met by the government.

These calculations are quite overall calculations, these obtained figures are open to debate. Therefore, what is important here is services that forest ecosystems receive within the scope of ecosystem services and the fact that these services are offered to public for free. Forest ecosystems reduce carbon footprint left by the humanity thanks to their carbon storage services. However, how and until when this process will continue shape humans' perspectives on natural environment and their consumption formats. In this context, chi square test was used to analyse participants' socio-demographic characteristics and whether they would support afforestation studies to reduce carbon footprint. According to the findings of analysis, statistically significant relationship was found between participants' age, education, profession and monthly income and the subject of "whether they would provide financial support in afforestation works towards reducing carbon emission". Statistically significant relationships were not determined between gender and participants' responses (Table 6).

Table 6. Participants' state of contribution to afforestation works

\begin{tabular}{c|c|c|c|c}
\hline Expression & Characteristics & $\chi 2$ & sd & p \\
\hline & Gender & 4.536 & 6 & 0.605 \\
"Whether they would provide financial support in & Age & 38.773 & 24 & $\mathbf{0 . 0 2 9}^{*}$ \\
afforestation works towards reducing carbon emission" & Education & 59.498 & 24 & $\mathbf{0 . 0 0 0}$ \\
& Occupation & 65.801 & 36 & $\mathbf{0 . 0 0 2}^{*}$ \\
\hline
\end{tabular}

$*<0.05$

Analysing the situation in terms of participants' ages according to assessments made, while individuals between 18-30 age group preferred contributing to afforestation works, other age groups did not prefer supporting these works. Analysing the situation in terms of participants' educational levels, it was determined that, as participants' educational level increased, their rate of financial contribution also increased. Analysing the situation in terms of participants' professions, it can be seen that housewives group preferred not to support and academician/educators group preferred supporting more. Analysing the situation in terms of monthly incomes, while low income groups preferred not to support, higher income groups preferred supporting.

\section{Participants' perceptions and attitudes towards ecosystem services and carbon footprints}

According to the results of reliability analysis conducted with regard to reliability of expressions towards measuring participants' perceptions and attitudes for their ecological footprints and their answers, Cronbach's Alpha was calculated as 0.702. This situation shows that expressions towards measuring participants' perceptions and attitudes and their answers were reliable. Analyses conducted towards these statements were listed based on averages of answers given, and they are presented in Table 7. Accordingly, the statement "I contribute to sustainable management of forests using 
certificated forest products" is the highest-level expression with a rate of 4.01 . The expression "I leave places clean in recreation and picnic fields" was the lowest rated expression with 1.48 rate. Analysing statements included in Table 7, it is remarkable that participants have quite complex attitudes towards reducing their ecological footprints.

\section{Discussion and conclusion}

The concept of ecological footprint was developed in the early 1990s and it is used for conducting ecological measurements. This criterion denominates biologically productive soil and water field in global hectares that are required for reproduction of resources consumed and disposal of waste created in the meantime by means of existing technology and resource management. In ecological footprint calculations, distinct components are used such as carbon footprint, cropland, forest land, grazing land, builtup land and fishing grounds. Among these footprints, carbon footprint was chosen in the study since it is dependent upon humans' consumption forms and it can be reduced by improving personal perceptions, attitudes and responsibilities.

Table 7. Participants' expressions on their perceptions and attitudes towards footprints

\begin{tabular}{|c|c|c|c|}
\hline Expressions & Mean & $\begin{array}{c}\text { Std. } \\
\text { deviation }\end{array}$ & Variance \\
\hline $\begin{array}{l}\text { I contribute to sustainable management of forests using certificated } \\
\text { forest products }\end{array}$ & 4.01 & 1.254 & 1.573 \\
\hline I prefer driving LPG vehicles rather than petrol-driven vehicles & 3.44 & 1.579 & 2.493 \\
\hline $\begin{array}{c}\text { I collect domestic wastes such as cardboard, paper, metal, plastic etc. in } \\
\text { different bags }\end{array}$ & 3.38 & 1.424 & 2.029 \\
\hline I plant saplings to reduce carbon emissions & 3.29 & 1.410 & 1.988 \\
\hline I do not prefer air transport which results in high $\mathrm{CO}_{2}$ emissions & 3.19 & 1.459 & 2.127 \\
\hline I prefer consuming white meat rather than red meat & 3.01 & 1.468 & 2.154 \\
\hline I prefer organic foods rather than hormone-injected foods & 2.74 & 1.088 & 1.183 \\
\hline $\begin{array}{l}\text { I carry out my responsibilities to maintain ecological functions of forest } \\
\text { ecosystems }\end{array}$ & 2.69 & 1.216 & 1.478 \\
\hline I prefer public transportation if travel distance is distant & 2.58 & 1.401 & 1.962 \\
\hline I travel to place in walking distance on foot or by bike & 2.41 & 1.364 & 1.861 \\
\hline $\begin{array}{l}\text { I plug out electronic appliances even when they are off since they } \\
\text { continue to spend electricity }\end{array}$ & 2.29 & 1.249 & 1.559 \\
\hline $\begin{array}{l}\text { I use energy saving bulbs at home, workplace or in office rather than } \\
\text { classical incandescent lamps }\end{array}$ & 2.23 & 1.347 & 1.815 \\
\hline $\begin{array}{l}\text { Forest ecosystems provide many benefits to society other than their } \\
\text { wood products }\end{array}$ & 2.16 & 1.163 & 1.352 \\
\hline $\begin{array}{c}\text { Services offered to society by forest ecosystems are important in terms } \\
\text { of their vital functions }\end{array}$ & 1.68 & 0.884 & 0.781 \\
\hline $\begin{array}{l}\text { Forest ecosystems are the most important component in prevention of } \\
\text { global warming }\end{array}$ & 1.65 & 0.885 & 0.783 \\
\hline I care not to waste water & 1.64 & 0.855 & 0.731 \\
\hline I leave recreation and picnic fields clean & 1.48 & 0.795 & 0.633 \\
\hline
\end{tabular}


Accordingly, the participants indicated that they can support afforestation works by a total amount of TRY 6150 to reduce their carbon footprint. Deducting this support amount from required investment amount, remaining investment of TRY 131130 should be met by the government. In other words, these services observed by forest ecosystems are provided to society for free by the Government. However, global footprint left by the humanity as of the 1970s has exceeded World's biocapacity, and emerging ecological deficit is increasing with each passing day. However, how and until when this process will continue will determine humans' perspectives on natural environment and their consumption habits. Besides, in the study, it is also seen that participants have quite complex attitudes towards reducing their ecological footprints. Participants' complex responses to the statements that were specified in terms of reduction of their ecological footprints also show that they should develop new behavior forms related to their perceptions, attitudes and responsibilities. In this case, it will be suitable that decision makers and authorities will take measures that will allow development of behavior patterns towards changing society's consumption habits and reducing their ecological footprints.

According to the results of study, humans leave their ecological footprints on the Earth event in their most basic choices (for instance, housing, nutrition, travel etc.). It is possible to reduce these footprints with some measures implemented (especially reduction of consumption, prevention of wasting resources etc.). However, forest ecosystems have a crucial role in reducing footprints. This service provided by forest ecosystems is of vital importance. Afforestation investments bear an important task in completing this service. Usually, governments do not demand a direct charge from citizens for such investments. However, this situation does not mean that society does not require environmental responsibility, on the contrary, it makes it necessary for society to become more sensitive. Besides, afforestation works contribute to not only carbon storage services but also provision of many services including regulation of water regime and precipitation, prevention of erosion, visual and aesthetic values etc. On the other hand, the carbon footprint is the total amount of carbon dioxide emissions that occur at each stage of the product life cycle (Wiedmann ve Minx, 2008). For this reason, forest ecosystems are used to store every ton of carbon released into the atmosphere. If the size and productivity of this forest ecosystem is not sufficient to store the amount of carbon released to the atmosphere, then the ecological deficit arises (Özsoy, 2015). Since 1961, Mediterranean countries have been in a situation of biocapcity deficit, with its demand for ecological services increasingly exceeding supply. In order to maintain this situation, the import of ecological assets from regions outside the Mediterranean is necessary. When Turkey is compared with Mediterranean countries in this aspect, only two countries provide approximately 50 percent of the natural endowment (biocapacity) of the Mediterranean basin: France (31\%) and Turkey (16\%). The ecological footprints of the Mediterranean countries show great differences among themselves. For example, three countries among Mediterranean countries alone contribute to more than 50 percent of the Mediterranean region's ecological footprint: France (20\%), Italy (19\%) and Spain (15\%) (Moore et al., 2018). Differences among countries' ecological footprint values are most likely driven by socio-economic factors, such as disposable income, infrastructure, and cultural habits (Baabou et al., 2017). Also, differences in consumption habits and quantities of these countries cause their footprints to be different. Especially food accounts for a large part of the Mediterranean countries' overall ecological footprint. According to result of other study, in 
Mediterranean countries food and beverages represents $28 \%$ of the regional ecological footprint (Galli, 2017). In also Turkey, ecological footprint of personal consumption is predominantly made up of food (52\%) (WWF, 2012). Mediterranean countries also vary considerably in terms of their food supply. Most countries in the region have a daily food supply that is $20 \%$ to $40 \%$ higher than the average FAO determined minimum daily dietary energy requirement benchmark of $2500 \mathrm{kcal} \mathrm{cap}^{-1} \mathrm{day}^{-1}$. Moreover, comparison of countries' food footprint intensities reveals a considerable spread, with the lowest value found in Egypt and the highest in Portugal (FAO et al., 1985; Pimentel and Pimentel, 2003). These comparisons and assessments show that our personal and social consumption behaviors need to be revised.

According to research findings, participants have quite complex attitudes towards reducing their ecological footprints. For example (Table 7), the statement " $i$ contribute to sustainable management of forests using certificated forest products" achieved the highest average, on the other hand, the expression "forest ecosystems are the most important component in prevention of global warming" achieved one of the lowest score averages with a rate of 1.65. Again similarly, while the idea of recycling wastes has a higher average score as a positive expression, reducing water waste has relatively lower average. These findings show that participants have some basic information and environmental responsibilities, also show that participants do not consider some components. A similar situation occurs between expressions "i plant saplings to reduce carbon emissions" (mean: 3.29) and "forest ecosystems are the most important component in prevention of global warming" (mean: 1.65). Accordingly, participants know that tree planting is effective in reducing carbon emissions, but they do not exhibit more sensitive approach. However, it shows that participants have low levels of awareness and sensitivity in terms of functions of forest ecosystems in prevention of global warming caused by carbon accumulation in the atmosphere $\left(\mathrm{CO}_{2}\right)$. These findings are important for future studies that will be conducted in the form of training, raising awareness and providing responsibility (Aoki and Akai, 2013; Sarıkaya et al., 2016). In addition, these data provide convenience for individuals following their resource use and sustainability (Mattila et al., 2011). On the other hand, these findings contribute to determination of social perceptions for planning and managing natural resources in a sustainable way. Thus, measures can be taken that will allow participants to reduce their ecological footprints. That is because people consume their natural resources rapidly and increase their ecological footprint amounts with each passing day.

Consequently, forest ecosystems carry out many vital services apart from being sources of wood origin products, and they bear vital importance for a sustainable life. Increasing society's level of knowledge and awareness related to forest ecosystems is significant in terms of ensuring continuity of ecosystem services and reducing ecological footprints left. However, it was found out that participants shaped components constituting their ecological footprints as per their consumption forms and they did not consider the effect of these behavior patterns in reducing their footprints. Therefore, public awareness should be raised in terms of vital importance of reducing ecological footprints, factors establishing ecological footprint and their relationships with each other. By acting as a whole for a sustainable life, ecological footprints should be reduced. This disrupted balance of the world is actually humanity's own balance. 


\section{REFERENCES}

[1] Akman, Y., Keteoğlu, O., Kurt, L., Evren. H., Düzenli, S. (2000): Environmental Pollution. - Palme Yayıncılık, Ankara (in Turkish).

[2] Albayrak, İ. (2012): Applicability of ecosystem services based watershed management model in İstanbul-Ömerli case. (Ph.D Thesis). - İstanbul Teknik University, Graduate School of Natural and Applied Sciences, İstanbul (in Turkish).

[3] Anna, K., Jaan-Henrik, K., Jakub, K., Dagmar, H. (2016): Ecosystem services in urban land use planning: Integration challenges in complex urban settings - Case of Stockholm. - Ecosystem Services 22: 204-212.

[4] Aoki, K., Akai, K. (2013): Does the Carbon Footprint Enhance the Sustainability Food Production and Transportation Service System? Real Buying Experiment in Japan. - In: Prabhu, V., Taisch, M., Kiritsis, D. (eds.) Advances in Production Management Systems. Sustainable Production and Service Supply Chains. APMS 2013. IFIP Advances in Information and Communication Technology, Vol. 415. Springer, Berlin, Heidelberg.

[5] Baabou, W., Grunewald, N., Ouellet-Plamondon, C., Gressot, M., Galli, A. (2017): The ecological footprint of Mediterranean cities: Awareness creation and policy implications. - Environmental Science \& Policy 69: 94-104.

[6] Boyd, J., Banzhaf, S. (2007): What are ecosystem services? The need for standardized environmental accounting units. - Ecological Economics 63: 616-626.

[7] Çoban, A., Yücel, M. (2018): The role of ecosystem services in urban planning. - Düzce University Journal of Science \& Technology 6: 444-454.

[8] Coşkun, A. A., Gençay, G. (2011): Kyoto Protocol and "deforestation" a legal analysis on Turkish environment and forest legislation. - Forest Policy and Economics 13: 366-377.

[9] Coşkun, I. Ç. (2013): Sınıf öğretmeni adaylarının ekolojik ayak izi farkındalık düzeylerinin belirlenmesi. (M.Sc. Thesis) - Gazi University, Educational Sciences Institute, Ankara (in Turkish).

[10] Costanza, R., d'Arge, R., De Groot, R., Farber, S., Grasso, M., Hannon, B., Limburg, K., Naeem, S., O’Neil, R. V., Paruelo, J., Raskin, G. R., Sutton, P., Belt, M. (1997): The value of the world's ecosystem services and natural capital. - Nature 387: 253-260.

[11] CSGB (2016). Ministry of Labour and Social Security. www.csgb.gov.tr/home/Contents/Istatistikler/AsgariUcret (accessed on 12.07.2018).

[12] Daily, G. C. (1997): Introduction: What are Ecosystem Services? Nature's Services Societal Dependence on Natural Ecosystems. - Island Press, Washington DC.

[13] De Groot, R. S., Wilson, M. A., Boumans, R. M. J. (2002): A typology for the classification, description and valuation of ecosystem functions, goods and services. Ecological Economics 41: 393-408.

[14] De Groot, R. S., Alkemade, R., Braat, L., Hein, L., Willemen, I. (2010): Challenges in integrating the concept of ecosystem services and values in landscape planning, management and decision making. - Ecological Complexity 7: 260-272.

[15] Demiroğlu, D., Karadağ, A. A. (2015): Ecosystem services approach to spatial planning in Turkey. - I. International Conference of Urban Studies, 16-17 April 2015, Eskişehir.

[16] Deniz, T., Ok, K. (2016): Valuation analysis in erosion control activities. - Istanbul University Journal of the Faculty of Forestry 66(1): 139-158.

[17] Dinç, A. (2015): Bir sürdürülebilir kalkınma göstergesi olarak ekolojik ayak izi ve Türkiye. (M.Sc. Thesis) - Anadolu University, Social Sciences Institute, Eskişehir (in Turkish).

[18] Ebad1, A., Moharram, N. N., Rahnamaee, M. T., Motesadı, Z. S. (2016): Determining the ecological footprint of vehicles in Tehran, Iran. - Applied Ecology and Environmental Research 14(3): 439-450.

[19] Ewing, B., Moore, D., Goldfinger, S., Oursler, A., Reed, A., Wackernagel, M. (2010): The Ecological Footprint Atlas. - Global Footprint Network, Oakland. 
[20] Eymen, U. E. (2007): SPSS 15.0 Veri Analiz Yöntemleri. - İstatistik Merkezi Yayınları, Ankara (in Turkish).

[21] FAO, WHO, UNU (1985): Protein and Energy Requirements. - Food and Agriculture Organization, World Health Organization, United Nations University, Rome, Italy.

[22] Galli, A., Iha, K., Halle, M., Bilali, H. E., Grunewald, N., Eaton, D., Capone, R., Debs, P., Bottalico, F. (2017): Mediterranean countries' food consumption and sourcing patterns: An Ecological Footprint viewpoint. - Science of the Total Environment 578: 383-391.

[23] Kalaycı, Ş. (2010): SPSS Uygulamalı Çok Değişkenli İstatistik Teknikleri. - Asil Yayın Dağıtım, Ankara (in Turkish).

[24] Kaypak, Ş. (2013): Ekolojik ayak izinden çevre barışına bakmak. - Turkish Journal of Scientific Reviews 6(1): 154-159 (in Turkish).

[25] Keleş, Ö. (2007): Application and evaluation of ecological footprint as an environmental education tool towards sustainable life. (Ph.D Thesis). - Gazi University, Department of Primary Education, Science Education Discipline, Ankara.

[26] Keleş, Ö., Uzun, N., Özsoy, S. (2008): Measuring and evaluating pre-service teachers' ecological footprints. - Ege Journal of Education 9(2): 1-14.

[27] Mancini, M. S., Galli, A., Niccolucci, V., Lin, D., Bastianoni, S., Wackernagel, M., Marchettini, N. (2016): Ecological footprint: Refining the carbon footprint calculation. Ecological Indicators 61: 390-403.

[28] Mattila, T., Kujanpaa, M., Dahlbo, H., Soukka, R., Myllymaa, T. (2011): Uncertainty and sensitivity in the carbon footprint of shopping bags. - Journal of Industrial Ecology 15(2): 217-227.

[29] MEA (2015): Ecosystems and Human Wellbeing: Synthesis. - Millennium Ecosystem Assessment, www.unep.org (accessed on 08.05.2018).

[30] Mendes, M., Pala, A. (2003): Type I error rate and power of three normality tests. Pakistan Journal of Information and Technology 2(2): 135-139.

[31] Moore, D., Brooks, N., Cranston, G., Galli, A. (2018): The Future of the Mediterranean. Tracking Ecological Footprint Trends, Interim Report for Comment. https://www.footprintnetwork.org/content/images/uploads/MAVA_report_5.pdf (accessed on 13.07.2018).

[32] OGM (2014): 298 Sayılı Tebliğ (Silvikültürel Uygulamaların Teknik Esasları). - General Directorate of Forestry, Ankara (in Turkish).

[33] Özmış, M., Tolunay, A. (2017): Determining the economic value of erosion control services and willingness to payment trends of society at Burdur region. - Süleyman Demirel University Journal of Natural and Applied Sciences 21(1): 99-112.

[34] Özsoy, C. E. (2015): Düşük karbon ekonomisi ve Türkiye'nin karbon ayak izi. - HAK-ìş Uluslararas1 Emek ve Toplum Dergisi 4(9): 198-2015 (in Turkish).

[35] Öztürk, A., Demirci, U., Türker, M. F. (2012): İklim değişikliği ile mücadelede karbon piyasaları ve Türkiye için bir değerlendirme. - KSU J. Nat. Sci. Special Edition: 306-312 (in Turkish).

[36] Öztürk, G. (2010): İlköğretim 7. Sınıflarda çevre eğitimi için ekolojik ayak izi kavramının kullanılması ve değerlendirilmesi. (M.Sc. Thesis) - Gazi University, Educational Sciences Institute, Ankara (in Turkish).

[37] Pamukoğlu, M. Y., Kırkan, B., Babalık, A. A. (2017): Assessment of the carbon footprint mass balance in the context of global climate change: A case study for Isparta Province. International Symposium on New Horizons in Forestry (ISFOR-2017), 18-20 Oct 2017, Isparta, Turkey.

[38] Pimentel, D., Pimentel, M. (2003): Sustainability of meat-based and plant-based diets and the environment. - Am. J. Clin. Nutr. 78(3): 660-663.

[39] Reyhan, A. S. (2014): Sürdürülebilir üretim-tüketim politikalari çerçevesinde "yeşil ekonomi” üzerine bir değerlendirme. - Memleket SiyasetYönetim (MSY) 9(22): 327-347 (in Turkish). 
[40] Sarıkaya, O., Babalık, A. A., Akten, M., Sarıkaya, A. G. (2016): The role of nature training for creating awareness of biological and cultural diversity with a case nature training project in Antalya, Turkey. - International Conference on Engineering and Natural Sciences, 24-28 May 2016, Sarajevo, Bosnia \& Herzegovina.

[41] Tavakol, M., Dennick, R. (2011): Making sense of Cronbach's alpha. - International Journal of Medical Education 2: 53-55.

[42] TEEB (2015): Integrating the ecological and economic dimensions in biodiversity and ecosystem service valuation. - The Economics of Ecosystems and Biodiversity, www.teebweb.org (accessed on 08.05.2018).

[43] Tosunoğlu, B. T. (2014): Ecological footprint as an indicator of global sustainable welfare. - HAK-iş Uluslararası Emek ve Toplum Dergisi 3(3): 132-149 (in Turkish).

[44] URL-1 (2018): Ekosistem Hizmetleri; doğanın insanlığa katkıları. http://www.dkm.org.tr/resources/files/ekosistem_hizmetleri_bilginotu.pdf (accessed on 08.05.2018).

[45] URL-2 (2018): National Footprint. - https://www.footprintnetwork.org/Global Footprint Network (accessed on 04.02.2018).

[46] URL-3 (2017): http://www.izmir.gov.tr/izmir-hakkinda. - Accessed on 04.12.2017.

[47] URL-4 (2017): http://www.karbonayakizi.com/calculator/calculator.aspx. - Accessed on 04.01.2018.

[48] Velioğlu, N., Aydin, A. (2017): Türkiye Ormanciliğinda Karbon Yönetiminin Hukuki Esaslari, Türkiye Ormancılar Derneği. - IV. Ulusal Ormanc1lık Kongresi İnsan-Doğa Etkileşiminde Orman ve Ormancılık, Antalya, Türkiye, 14 Kasım - 17 Aralık 2017, pp.12-19 (in Turkish).

[49] Wackernagel, M., Rees, W. E. (1996): Our Ecological Footprint: Reducing Human Impact on the Earth. - New Society Publishers, Gabriola Island, BC, Canada.

[50] Wackernagel, M., Cranston, G., Morales, J. C., Galli, A. (2014): Ecological Footprint Accounts. - In: Atkinson, G., Dietz, S., Neumayer, E., Agarwala, M. (eds.). Handbook of Sustainable Development, second revised edition, pp. 371-398. Edward Elgar Publishing, Cheltenham, Glos, UK.

[51] Wiedmann, T., Minx, J. (2008): A Definition of 'Carbon Footprint'. - In: Pertsova, C. C. (ed.) Ecological Economics Research Trends: Chapter 1, pp. 1-11. Nova Science Publishers, Hauppauge NY, USA.

[52] William, E. R. (1992): Ecological footprints and appropriated carrying capacity: What urban economics. - Environment and Urbanization 4: 121-130.

[53] Wilson, J., Anielski, M. (2005): Ecological Footprints of Canadian Municipalities and Regions. The Canadian Federation of Canadian Municipalities. - Edmonton: Anielski Management Inc. Alberta, Canada.

[54] WWF (2012): Turkey's Ecological Footprint Report. Global Footprint Network. http://www.footprintnetwork.org/content/images/article_uploads/Turkey_Ecological_Foo tprint_Report_Turkish.pdf (accessed on 02.01.2018). 


\section{APPENDIX}

\section{Survey Form}

"Determination of Environmental Perceptions and Awareness Towards Reducing Carbon Footprint."
1. Gender:
( ) Female
() Male

2. Age group:

$\begin{array}{ll}\text { ( ) } 18-30 & \text { ( ) } 31-40\end{array}$

( ) Primary school graduate

( ) $41-50$

( ) $51-60$

( ) $60<$

3. Education level:
( ) High school graduate

( ) University graduate

( ) Postgraduate

4. Work/Professional: ( ) Officer

( ) Self-employed

( ) Engineer

( ) Housewife

( ) Unemployed

( ) Retired

( ) Educator

5. Income level:
( ) 0 - 1000 TRY
( ) 1001 - $2000 \mathrm{TRY}$
( ) 2001 - 3000 TRY
( ) $3001-4000$ TRY
( ) $4000<\mathrm{TRY}$

6. Your meal preference: ( )I'm a vegetarian. ( )I usually consume fish. ( )I usually consume white meat. ( ) I consume red and white meat. ( ) I consume red meat every day.

7. Your organic food consumption preference:
( ) I only buy organic products.
( ) Some of the products I buy are organic.
( ) I do not buy any organic products.
( ) I don't know if you buy organic products.

8. Your clothing preference: () I use second-hand clothes. ( ) I buy new clothes if I need them.
( ) I follow the latest fashion.

\section{Imported food and product consumption preference:}

( ) I just consume domestic products.

( ) I usually consume domestic products.

( ) I rarely prefer to consume domestic products.

( ) Domestic or imported products, it does not matter to me.

10. Your furniture and electronics goods preference:

( ) I usually buy new products, but I use them for at least 5 years.

( ) I buy the latest technology or fashionable products.

11. Your recycling preference:
( ) All my garbage is recycled.
( ) Most of my garbage is recycled.
( ) Some of the my garbage is recycled.
( ) My garbage is not recycled.

\section{Your entertainment activities:}

( ) I do activities that do not produce carbon (e.g. walking, cycling).

( ) I usually go to movies, bars and restaurants.

( ) I make intensive carbon-producing activities (e.g. flight, motorcycle).
13. How many cars do you have?: ( ) 1
( ) 2
( ) Three and over
( ) I do not have a car

14. Your annual energy consumption:
( ) Electricity use $(\mathrm{kWh})$
( ) Natural gas (m3)
( ) Coal (Ton)
( ) LPG (Liter).
( ) Other. 
15. Number of round-trip flights per year:

( ) Short-haul flights (Turkey-Europe)

( ) Medium-haul flights (Turkey-China)

( ) Long-haul flights (Turkey-America)

16. Traveling by car: ( ) Car model.

( ) The annual amount of distance $(\mathrm{km})$.

17. The annual distance from your travel by bus and train $(\mathrm{km})$ ?
( ) Bus
( ) Train
( ) Light rail.
( ) Subway.

18. Trees are one of the most important elements that reduce carbon dioxide emissions and store carbon. Therefore do you want to provide financial support for afforestation efforts to reduce carbon emissions?
( ) 10 TRY
( )20 TRY
( ) 30 TRY
( ) 40 TRY
( ) 50 TRY
( ) $100 \mathrm{TRY}$
( ) No

Mark the following expressions as appropriate.

\begin{tabular}{|c|c|c|c|c|c|}
\hline Expressions & Always & Often & Sometimes & Rarely & Never \\
\hline $\begin{array}{l}\text { I travel to place in walking distance on foot or by } \\
\text { bike. }\end{array}$ & & & & & \\
\hline $\begin{array}{l}\text { I prefer public transportation if travel distance is } \\
\text { distant. }\end{array}$ & & & & & \\
\hline $\begin{array}{l}\text { I prefer driving LPG vehicles rather than petrol- } \\
\text { driven vehicles. }\end{array}$ & & & & & \\
\hline $\begin{array}{l}\text { I do not prefer air transport which results in high } \mathrm{CO} 2 \\
\text { emissions. }\end{array}$ & & & & & \\
\hline $\begin{array}{l}\text { I plug out electronic appliances even when they are } \\
\text { off since they continue to spend electricity. }\end{array}$ & & & & & \\
\hline $\begin{array}{l}\text { I use energy saving bulbs at home, workplace or in } \\
\text { office rather than classical incandescent lamps. }\end{array}$ & & & & & \\
\hline $\begin{array}{l}\text { I collect domestic wastes such as cardboard, paper, } \\
\text { metal, plastic etc. in different bags. }\end{array}$ & & & & & \\
\hline I care not to waste water. & & & & & \\
\hline I leave recreation and picnic fields clean. & & & & & \\
\hline I plant saplings to reduce carbon emissions. & & & & & \\
\hline $\begin{array}{l}\text { I prefer organic foods rather than hormone-injected } \\
\text { foods. }\end{array}$ & & & & & \\
\hline I prefer consuming white meat rather than red meat. & & & & & \\
\hline $\begin{array}{l}\text { I contribute to sustainable management of forests } \\
\text { using certificated forest products. }\end{array}$ & & & & & \\
\hline $\begin{array}{l}\text { I carry out my responsibilities to maintain ecological } \\
\text { functions of forest ecosystems. }\end{array}$ & & & & & \\
\hline $\begin{array}{l}\text { Forest ecosystems provide many benefits to society } \\
\text { other than their wood products. }\end{array}$ & & & & & \\
\hline $\begin{array}{l}\text { Services offered to society by forest ecosystems are } \\
\text { important in terms of their vital functions. }\end{array}$ & & & & & \\
\hline $\begin{array}{l}\text { Forest ecosystems are the most important component } \\
\text { in prevention of global warming. }\end{array}$ & & & & & \\
\hline
\end{tabular}

